\title{
HUBUNGAN ANTARA AKTIVITAS FISIK DAN ANGKA KECUKUPAN GIZI MAKRONUTRIEN TERHADAP RASIO KOLESTEROL TOTAL/HDL PADA MASYARAKAT PEDESAAN
}

\section{CORRELATION BETWEEN PHYSICAL ACTIVITY AND MACRONUTRIENT RECOMMENDED DIETARY ALLOWANCE TOWARD THE TOTAL CHOLESTEROL/HDL RATIO IN PEOPLE LIVING IN RURAL AREA}

\author{
Utari Febrina Supomo Sunu*), Galih Permadi, Fenty \\ Fakultas Farmasi, Universitas Sanata Dharma, Kampus III Maguwoharjo Depok Sleman, \\ Yogyakarta 55282, Indonesia
}

Received February 23, 2017; Accepted March 30, 2017

\begin{abstract}
Cardiovascular disease is the number one cause of death in the world. The disease is influenced by several factors such as lack of physical activity, imbalanced nutritional intake, and high blood cholesterol levels. The value of the total cholesterol / HDL can predict cardiovascular disease risk factors. The study aims to investigate the relationship between physical activity and Dietary Allowances of the macronutrient and ratio total cholesterol / HDL in rural communities. This is observational analytic with cross-sectional design of the 102 respondents (male: 40, female: 62) in Kepuharjo village, Cangkringan, Sleman, Yogyakarta, with a purposive sampling techniques. Physical activity data were taken using a structured interview (Baecke) and Semi Quantitive Food Frequency Questionnaire (SQFFQ) for data macronutrient, while blood total cholesterol and HDL-cholesterol levels were analyzed using enzymatic methods. The results of the study showed that there is no significant relationship between physical activity and the ratio of total cholesterol / HDL ( $p=0.038$; CI 95\%: 0.9861.33), dietary allowances of the macronutrient energy and the ratio of total cholesterol / HDL $(p=0.068)$, protein intake on the ratio of total cholesterol / HDL $(p=1.000)$, fat intake to the ratio of total cholesterol / HDL $(p=0.081)$, and the intake of carbohydrates to the ratio of total cholesterol / HDL ( $p=0.088)$. In conclusion there is no significant relationship between physical activity and dietary allowance of macronutrient towards to the ratio of total cholesterol / HDL.
\end{abstract}

Keywords: physical activity, dietary allowance of macronutrient, ratio of total cholesterol/HDL

\begin{abstract}
ABSTRAK
Penyakit kardiovaskular merupakan penyebab kematian nomor satu di dunia. Penyakit ini dipengaruhi oleh beberapa faktor seperti, kurangnya aktivitas fisik, konsumsi gizi yang tidak seimbang dan kadar kolesterol darah yang tinggi. Salah satu cara untuk memprediksi faktor risiko penyakit kardiovakular adalah dengan menggunakan nilai rasio kolesterol total/HDL. Penelitian ini bertujuan untuk mengetahui hubungan antara aktivitas fisik dan angka kecukupan gizi (AKG) makronutrien terhadap rasio kolesterol total/HDL pada masyarakat pedesaan. Jenis dari penelitian ini adalah observasional analitik dengan rancangan potong lintang pada 102 responden (pria: 40, wanita: 62) di Desa Kepuharjo, Kecamatan Cangkringan, Sleman, Yogyakarta, dengan teknik purposive sampling. Data aktivitas fisik diambil dengan
\end{abstract}

*Corresponding author: Utari Febrina Supomo Sunu

Email: utarifss@gmail.com 
menggunakan panduan wawancara terstruktur Baecke dan Semi Quantitive Food Frequency Questionnaire (SQFFQ) untuk data AKG makronutrien, sedangkan kadar kolesterol darah dan HDL responden dianalisis dengan menggunakan metode enzimatis. Hasil dari penelitian aktivitas fisik menunjukkan bahwa tidak terdapat hubungan yang bermakna antara aktivitas fisik terhadap rasio kolesterol total/HDL ( $\mathrm{p}=0,038$; nilai CI 95\%: 0,98-61,33). Hasil penelitian AKG makronutrien menunjukkan bahwa tidak terdapat hubungan yang signifikan antara asupan energi terhadap rasio kolesterol total/HDL $(\mathrm{p}=0,068)$, asupan protein terhadap rasio kolesterol total/HDL ( $\mathrm{p}=1,000)$, asupan lemak terhadap rasio kolesterol total/HDL ( $\mathrm{p}=0,081)$, dan asupan karbohidrat terhadap rasio kolesterol total/HDL $(\mathrm{p}=0,088)$. Kesimpulannya tidak terdapat hubungan yang bermakna antara aktivitas fisik dan angka kecukupan gizi makronutrien terhadap rasio kolesterol total/HDL.

Kata kunci: aktivitas fisik, AKG makronutrien, rasio kolesterol total/HDL

\section{PENDAHULUAN}

Penyakit kardiovaskular merupakan penyebab kematian nomor satu di dunia. Pada tahun 2015, 17,5 juta orang meninggal dunia setiap tahunnya akibat penyakit kardiovaskular dan diperkirakan $31 \%$ dari kematian di seluruh dunia. Penyakit kardiovakular menyebabkan $75 \%$ kematian yang terjadi di negara-negara berpendapatan menengah dan rendah di dunia, salah satunya Indonesia. (WHO, 2015).

Faktor risiko terjadinya penyakit kardiovaskular antara lain umur, jenis kelamin, obesitas, displidemia, merokok, status menopause pada wanita, kurangnya aktivitas fisik dan konsumsi makanan yang tidak sehat (Heart UK, 2015). Aktivitas fisik merupakan segala pergerakan tubuh yang dihasilkan oleh otot rangka dan akan meningkatkan pengeluaran energi $(\mathrm{NIH}$, 2012). Aktivitas fisik berupa olahraga dan kegiatan harian yang dilakukan secara rutin dapat menurunkan risiko penyakit kardiovakular dengan menjaga stabilitas sistem kerja jantung dan menyeimbangkan kadar kolesterol darah (Ignarro et al. 2007; Miles 2007).Makanan yang tidak sehat adalah makanan yang tidak mengandung gizi seimbang seperti karbohidrat, protein, mineral, vitamin dan lemak tak jenuh. Konsumsi gizi yang berlebihan juga tidak baik bagi kesehatan. Konsumsi gizi yang berlebihan seperti masukan energi dari karbohidrat, lemak, protein maupun alkohol dapat menaikan kolesterol dalam darah. Hal tersebut akan meningkatkan risiko penyakit kardiovaskular (WHO, 2016).

Nilai rasio kolesterol/HDL dapat menujukkan risiko terjadinya aterosklerosis (Dipiro, 2008). Penumpukan plak (aterosklerosis) ini mempersempit dinding arteri sehingga mempersulit darah untuk mengalir dan dapat menghentikan aliran darah. Hal ini dapat menyebabkan serangan jantung dan stroke (AHA, 2015). Menurut Pereira (2012) pengukuran rasio lipid merupakan prediktor yang akurat, salah satunya adalah rasio kolesterol total/HDL yang merupakan prediktor tunggal terbaik untuk melihat risiko penyakit kardiovakular. Menurut Arisman (2011), rasio kolesterol total/HDL tinggi menunjukan risiko terkena serangan jantung bagi wanita maupun lakilaki. Semakin kecil nilai rasio kolesterol total/HDL, maka semakin rendah risiko penyakit kardiovaskular (Milan, et al., 2009).

Pada penelitian kali ini dilakukan pada masyarakat Desa Kepuharjo, Kecamatan Cangkringan, Sleman, Yogyakarta, dimana pada daerah tersebut secara umum masih belum memiliki akses yang memadai untuk dapat menjangkau fasilitas-fasilitas kesehatan, baik karena kurangnya tenaga ahli kesehatan ataupun faktor ekonomi (WHO, 2008).

Berdasarkan uraian diatas, penelitian ini cukup penting dilakukan untuk mengetahui adanya pengaruh aktivitas fisik yang dilakukan sehari-hari dan asupan makanan yang dikonsumsi oleh masyarakat 
di pedesaan melalui panduan wawancara akitivitas fisik dan angka kecukupan gizi makronutrien terhadap rasio kolesterol total/HDL sebagai faktor risiko penyakit kardiovaskular.

\section{METODE PENELITIAN}

Jenis penelitian ini adalah penelitian observasional analitik dengan rancangan potong lintang (cross sectional). Responden penelitian yaitu masyarakat Desa Kepuharjo, Cangkringan, Sleman, Yogyakarta berumur 40-60 tahun, dan telah menandatangani informed consent. Pengambilan sampel responden digunakan non probability sampling dengan teknik purposive sampling. Adapun kriteria ekslusi penelitian ini adalah orang dewasa yang memiliki kecacatan fisik sehingga tidak dapat melakukan aktivitas fisik,sedang menjalani diet, memiliki riwayat penyakit jantung, wanita hamil, tidak hadir saat pengambilan data, tidak berpuasa selama 10-12 jam sebelum pengambilan darah, dan hasil pemeriksaan responden tidak lengkap. Responden yang mengikuti penelitian ini berjumlah 102 orang terdiri dari 40 pria dan 62 wanita. Penelitian yang dilakukan telah mendapat izin dari Badan Perencanaan Pembangunan Daerah Pemerintah Kabupaten Sleman. Prosedur yang digunakan dalam penelitian telah disetujui oleh Komisi Etik Penelitian Kedokteran dan Kesehatan Fakultas Kedokteran Universitas Gajah Mada Yogyakarta nomor: KE/FK/797/EC/2016.

\section{Pengumpulan Data}

Pengumpulan data yang dilakukan dalam penelitian ini adalah mengukur berat badan, tinggi badan, aktivitas fisik dengan metode wawancara yang mengacu pada panduan wawancara terstruktur Baecke (Lita, 2016), dan angka kecukupan gizi makronutrien dengan metode wawancara semi quantitive food frequency questionnaire (SQFFQ) (Fridawanti, 2015). Alat pengukur berat badan yang digunakan adalah timbangan badan digital dan alat pengukur tinggi badan yang telah divalidasi di Balai Meterologi Yogyakarta. Sampel darah responden (kolesterol total dan HDL) dianalisis pada laboratorium yang telah terakreditasi di Yogyakarta dengan metode enzimatis (NHANES, 2007).Analisis data statistik dilakukan di Clinical Epidemiology and Biostatistic Unit (CE\&BU) Fakultas Kedokteran Universitas Gadjah Mada Yogyakarta yang diolah dengan program IBM SPSS 22 dengan taraf kepercayaan $95 \%$.

\section{Penilaian Aktivitas Fisik}

Menurut AHA dan American College of Sports Medicine, aktivitas fisik dihitung berdasarkan nilai perkiraan pengeluaran energi pada kegiatan tertentu, data tersebut diperoleh melalui kuisoner recall aktivitas fisik kegiatan yang biasa dilakukan dalam sehari. Kuisoner ini terdiri dari 15 pertanyaan berdasarkan aktivitas harian yang dilakukan oleh responden (7 pertanyaan indeks kerja; 4 pertanyaan indeks olahraga; dan 4 pertanyaan indeks waktu luang). Setiap pertanyaan memiliki penilaian dan poin masing-masing, kemudian keseluruhan poin dari tiga indeks tersebut dijumlahkan dan hasilnya menjadi kategori aktivitas fisik responden. Aktivitas fisik tersebut dibagi berdasarkan intensitasnya menjadi 3 kategori, yaitu ringan $(<5,6)$, sedang $(5,6-$ $7,9)$, dan berat $(>7,9)$ (Widiantini \& Tafal, 2014). Penilaian aktivitas fisik menurut kuisoner Baecke terdiri dari indeks kerja (IK), indeks olahraga (IO), dan indeks waktu luang (IWL) (Anggraeni, 2008). IK dibagi menjadi 3 yaitu ringan (supir, guru, pensiunan, pedagang menetap, pegawai negeri sipil, dan ibu rumah tangga); sedang (buruh pabrik); dan berat (buruh bangunan, pedagang keliling, dan petani). IO dibagi menjadi 3 yaitu olahraga ringan dimana ratarata memerlukan energi sebanyak $0,76 \mathrm{MJ} / \mathrm{h}$ (golf, memancing, dan peregangan tubuh); olahraga sedang rata-rata energi yang dibutuhkan 1,26 MJ/h (bulu tangkis, bersepeda, tenis, jogging, senam, berenang, dan voli); dan olahraga berat rata-rata energi yang dibutuhkan 1,76 MJ/h (basket, sepak bola, dan futsal). IWL dibagi berdasarkan durasi aktivitas fisik yang dilakukan pada 
waktu luang setiap hari ( $<5$ menit; 5 menit15 menit; 15 menit-30 menit; 30menit-45 menit; >45 menit).

\section{Penilaian Angka Kecukupan Gizi Makronutrien}

Semi quantitive food frequency questionnaire (SQFFQ) adalah instrument penilaian makanan atau gizi dengan mengambil data dari makanan yang dikonsumsi beserta frekuensi konsumsinya. Peneliti menanyakan ukuran atau porsi makanan (sedikit, sedang, dan banyak) dan jenis makanan yang dimakan. Semua porsi makanan dikalkulasikan menjadi perhari menggunakan program nutrisurvey (Coates, et al., 2012). Cara perhitungan nilai frekuensi makanan sesuai dengan penelitian Saevageot et al,(2013) kemudian dibandingkan dengan nilai standar Menteri Kesehatan RI. Panduan wawancara SQFFQ yang digunakan sesuai dengan penelitian Fridawanti (2015) yang dilakukan pada masyarakat dengan daerah dan karakteristik yang sama. Panduan wawancara ini telah di validasi dengan melakukan analisis situasi dan menambahkan gambar- gambar penunjang serta tambahan data makanan yang dikonsumsi masyarakat Desa Kepuharjo.

\section{Faktor Risiko Penyakit Kariovaskular}

Kriteria tersebut digunakan untuk melihat faktor risiko penyakit kardiovaskular dinilai dari rasio kolesterol total/HDL. Rasio kolesterol total/HDL dibagi menjadi 3 kategori yaitu untuk pria/wanita postmenopause rendah $<3,5$; sedang 3,5-5,0; dan tinggi $>5,0$, sedangkan untuk wanita premenopause rendah $<3,0$; sedang 3,0-4,5; dan tinggi >4,5 (Milan et al., 2009).

\section{Analisis Statistik}

Pengolahan data dilakukan di Pusat Kajian CE\&BU dengan menggunakan program IBM SPSS 22. Uji Mann-Whitney dilakukan untuk melihat perbandingan antara responden yang berisiko CVD dan tidak berisiko CVD terhadap variabel terkait (AKG, aktivitas fisik, usia, dan BMI). Uji komparatif dilakukan menggunakan uji Fisher antara aktivitas fisik terhadap rasio kolesterol total/HDL. Hubungan angka kecukupan gizi makronutrien terhadap rasio kolesterol/HDL di uji menggunakan uji ChiSquare. Uji signifikansi antara data yang diobservasi dengan data yang diharapkan dilakukan dengan taraf kepercayaan 95\% (Dahlan, 2014).

Tabel I. Karakteristik Demografi Responden Penelitian

\begin{tabular}{llccc}
\hline \multirow{2}{*}{ Variabel } & & Pria $(\mathrm{n}=40)$ & Wanita $(\mathrm{n}=62)$ & $\begin{array}{c}\text { Total } \\
(\mathrm{n}=100) \\
\mathrm{n}(\%)\end{array}$ \\
& & $\mathrm{n}(\%)$ & & $\mathrm{n}(\%)$ \\
\hline Usia (tahun) & $40-49$ & $14(13,7)$ & $37(36,3)$ & $51(50)$ \\
Aktivitas Fisik & $50-60$ & $26(25,5)$ & $25(24,5)$ & $51(50)$ \\
& Ringan & $1(1,0)$ & $25(24,5)$ & $26(25,5)$ \\
& Sedang & $35(34,3)$ & $37(36,3)$ & $72(70,6)$ \\
Energi & Berat & $4(3,9)$ & $0(0,0)$ & $4(3,9)$ \\
& Lebih & $20(19,61)$ & $31(30,39)$ & $51(50,00)$ \\
& Cukup & $9(8,82)$ & $15(14,71)$ & $24(23,53)$ \\
Protein & Rendah & $11(10,78)$ & $16(15,69)$ & $17(16,67)$ \\
& Lebih & $23(22,55)$ & $35(34,31)$ & $58(56,86)$ \\
& Cukup & $9(8,82)$ & $17(16,67)$ & $26(25,49)$ \\
& Rendah & $8(7,84)$ & $10(9,80)$ & $18(17,65)$ \\
\hline
\end{tabular}




\begin{tabular}{|c|c|c|c|c|}
\hline \multirow[t]{3}{*}{ Lemak } & Lebih & $12(11,76)$ & $29(28,43)$ & $41(40,20)$ \\
\hline & Cukup & $12(11,76)$ & $13(12,75)$ & $25(24,51)$ \\
\hline & Rendah & $16(15,69)$ & $20(19,61)$ & $36(35,29)$ \\
\hline \multirow[t]{3}{*}{ Karbohidrat } & Lebih & $18(17,65)$ & $30(29,41)$ & $48(47,06)$ \\
\hline & Cukup & $9(8,82)$ & $17(16,67)$ & $26(25,49)$ \\
\hline & Rendah & $13(12,75)$ & $15(14,71)$ & $28(27,45)$ \\
\hline \multirow[t]{3}{*}{$\mathrm{TC}(\mathrm{mg} / \mathrm{dL})$} & Rendah & $16(15,7)$ & $26(25,5)$ & $42(41,2)$ \\
\hline & Sedang & $16(15,7)$ & $20(19,6)$ & $36(35,3)$ \\
\hline & Tinggi & $8(7,8)$ & $16(15,7)$ & $24(23,5)$ \\
\hline \multirow[t]{3}{*}{$\mathrm{HDL}(\mathrm{mg} / \mathrm{dL})$} & Rendah & $5(4,9)$ & $2(2,0)$ & $7(6,9)$ \\
\hline & Sedang & $28(27,5)$ & $42(41,2)$ & $70(68,6)$ \\
\hline & Tinggi & $7(6,9)$ & $18(17,6)$ & $25(24,5)$ \\
\hline \multirow[t]{3}{*}{ TC/HDL Ratio } & Rendah & $8(7,8)$ & $11(10,8)$ & $19(18,6)$ \\
\hline & Sedang & $23(22,5)$ & $37(36,3)$ & $60(58,8)$ \\
\hline & Tinggi & $9(8,8)$ & $14(13,7)$ & $23(22,5)$ \\
\hline \multirow[t]{2}{*}{ Status Merokok (\%) } & Tidak & $25(24,5)$ & $62(60,8)$ & $87(85,3)$ \\
\hline & Ya & $15(14,7)$ & $0(0,0)$ & $15(14,7)$ \\
\hline \multirow[t]{2}{*}{ Status Menopause (\%) } & Tidak & $0(0,0)$ & $37(59,7)$ & $37(59,7)$ \\
\hline & $\mathrm{Ya}$ & $0(0,0)$ & $25(40,3)$ & $25(40,3)$ \\
\hline \multirow[t]{4}{*}{ IMT(kg/m2) } & Underweight & $2(2,0)$ & $2(2,0)$ & $4(3,9)$ \\
\hline & Normal & $19(18,6)$ & $14(13,7)$ & $33(32,4)$ \\
\hline & Overweight & $9(8,8)$ & $13(12,7)$ & $22(21,6)$ \\
\hline & Obesitas & $10(9,8)$ & $33(32,4)$ & $43(42,2)$ \\
\hline
\end{tabular}

*TC: Kolesterol Total; TC/HDL Ratio: Rasio Kolesterol Total/HDL; IMT: Index Massa Tubuh; Lebih: >110\% ; Cukup: 90-110\%; Rendah: <90\%.

\section{HASIL DAN PEMBAHASAN Karakteristik Subjek Penelitian}

Hasil analisis statistik karakteristik responden (Tabel I) menunjukkan bahwa penduduk Desa Kepuharjo yang paling banyak melakukan aktivitas fisik ringan dan sedang adalah wanita. Penelitian ini sesuai dengan penelitian yang dilakukan oleh Sudikno, Herdayati, dan Basral (2010) bahwa presentase aktivitas fisik yang ringan pada wanita lebih banyak $(62,47 \%)$ dibandingakan dengan pria $(58,48 \%)$. Aktivitas fisik berat keseluruhan dilakukan oleh pria sebesar $4 \%$ dan tidak ada wanita yang melakukan aktivitas fisik berat.

Tabel I juga menunjukan bahwa 50\% responden di Desa Kepuharjo mempunyai asupan energi berlebih. Hal diatas menunjukan bahwa responden mengonsumsi makanan yang berlebih dan tidak sesuai dengan angka kecukupan gizi yang ditentukan oleh Menteri Kesehatan RI tahun 2013.

Hasil perbandingan diatas menunjukkan bahwa tidak ada hubungan yang bermakna secara statistik (nilai $\mathrm{p}>$ $0,05)$ antara angka kecukupan gizi 
makronutrien terhadap risiko CVD, walaupun responden yang memiliki angka kecukupan gizi makronutrien lebih tinggi cenderung tidak berisiko terkena CVD. Hal tersebut sejalan dengan penelitian Huang et al. (2014) yang dilakukan pada 3.350 responden, hasilnya menunjukkan bahwa asupan gizi di Taiwan mempunyai hubungan yang tidak bermakna terhadap risiko penyakit kardiovaskular. Responden yang melakukan aktivitas fisik yang tinggi akan memiliki risiko terkena penyakit kardiovaskular yang lebih rendah dibandingkan dengan dengan responden yang kurang melakukan aktivitas fisik. Aktivitas fisik berupa kegiatan harian ataupun olahraga dengan intensitas yang tepat dan teratur merupakan pola hidup yang sehat mempunyai pengaruh pada penyakit kardiovaskular (Elizabeth et al., 2012). Aktivitas fisik yang tinggi dapat menghidarkan dari proses arterosklerosis, yaitu penumpukan kolesterol terutama LDL pada dinding arteri (Sumosardjuno, 2007).

Tabel II menunjukan rerata BMI responden yang mempunyai risiko CVD lebih tinggi daripada yang tidak berisiko CVD.Nilai body mass index yang tinggi merupakan salah satu faktor risiko penyakit kardiovaskular. Menurut penelitian Mohammadifard, et al., (2013) yang dilakukan pada 6.335 responden dengan rerata Body Mass Index $(25,6 \pm 4,8)$ hampir sama dengan hasil penelitian ini, menunjukan risiko penyakit kardiovaskular. Proporsi penyakit kardiovaskular pada penelitian Ghanbari, et al., (2014) lebih banyak terjadi pada responden dengan rerata BMI yang tinggi daripada BMI dengan rerata rendah. Penelitian Chen, et al., (2013), Huang, et al., (2014) menunjukan hubungan BMI dengan risiko penyakit kardiovaskular di Asia. Tingginya nilai BMI merupakan faktor risiko mortalitas akibat penyakit kardiovaskulardi Asia. Rerata BMI yang tinggi pada penelitian Valentino, et al., (2015) dengan 99 responden pria dan 83 responden wanita di Chille berhubungan dengan faktor risiko penyakit kardiovaskular.
Hasil uji Chi-Square tersebut menunjukan hubungan yang tidak bermakna antara asupan energi, protein, lemak dan karbohidrat terhadaprasio kolesterol total/HDL pada responden. Penelitian Ekasari (2013) sejalan dengan penelitian ini yang menjelaskan hubungan tidak bermakna antara asupan karbohidrat, protein, lemak, dan kolesterol terhadap penyakit jantung koroner dan non koroner. Penelitian Ghanbari, et al., (2014) pada 403 responden di Iran menunjukan hubungan yang tidak bermakna antara asupan gizi dan penyakit jantung koroner. Penelitian Fridawanti (2015) pada 100 responden terdiri dari 50 pria dan 50 wanita yang menunjukan hubungan tidak bermakna antara asupan energi, protein, dan lemak terhadap obesitas pada orang dewasa di pedesaan. Obesitas adalah salah satu faktor risiko penyakit kardiovaskular. Penelitian Loong, Mayulu, dan Kawengian (2013), menemukan hubungan yang tidak bermakna antara asupan zat gizi makro dengan obesitas pada wanita usia subur di Manado.

Hasil penelitian yang dilakukan Yuliantini, Sari, dan Nur (2015) yang melihat hubungan asupan energi, lemak, dan serat terhadap rasio kolesterol total/HDL pada 45 responden di Bengkulu berbeda dengan hasil penelitian ini. Adanya hubungan yang bermakna antara asupan energi dan asupan lemak dengan rasio kolesterol total/HDL dan menunjukan bahwa semakin tinggi asupan lemak, maka rasio kolesterol total/HDL juga semakin meningkat. Tingginya rasio kolesterol/HDLdapat meningkatkan risiko terjadinya penyakit kardiovaskular, hal ini disebabkan karena jumlah lipid yang meningkat dalam darah yang mengakibatkan terbentuknya plak di pembuluh darah jantung hingga terjadi aterosklerosis (McPhee dan Ganong, 2011).Menurut penelitian Shay, et al., (2012) pada 17 sampel populasi (4680 responden) di China, Japan, UK, dan US berumur 40-59 tahun menunjukan asupan makronutrien mempunyaiodds ratio yang besar terhadap risiko rendah CVD. 
Tabel II. Hasil Perbandingan antara Responden yang Berisiko CVD dan Tidak Berisiko CVD terhadap Variabel Terkait

\begin{tabular}{|c|c|c|c|}
\hline Variabel & Risiko CVD $(n=79)$ & $\begin{array}{c}\text { Bukan Risiko CVD } \\
\qquad(\mathrm{n}=23)\end{array}$ & Nilai $p$ \\
\hline AKG Energi & $118,38 \pm 45,94$ & $125,39 \pm 42,70$ & 0,162 \\
\hline AKG Protein & $137,91 \pm 56,05$ & $156,19 \pm 63,95$ & 0,182 \\
\hline AKG Lemak & $108,96 \pm 49,01$ & $129,55 \pm 63,93$ & 0,066 \\
\hline AKG Karbohidrat & $125,66 \pm 56,65$ & $132,37 \pm 33,52$ & 0,125 \\
\hline Aktivitas Fisik & $6,16 \pm 0,67$ & $6,49 \pm 0,67$ & 0,290 \\
\hline Usia & $49,01 \pm 5,40$ & $51,39 \pm 6,90$ & 0,159 \\
\hline BMI (Body Mass Index) & $25,08 \pm 4,60$ & $23,67 \pm 4,31$ & 0,257 \\
\hline
\end{tabular}

*Nilai p diperoleh dari uji Mann-Whitney

Tabel III. Hubungan Angka kecukupan Gizi Makronutrien dan Aktivitas Fisik terhadap Rasio Kolesterol Total/HDL

\begin{tabular}{|c|c|c|c|c|c|c|}
\hline \multirow[b]{2}{*}{ Variabel } & \multicolumn{2}{|c|}{$\begin{array}{l}\text { Rasio Kolesterol } \\
\text { Total/HDL }\end{array}$} & \multirow[b]{2}{*}{$\begin{array}{l}\text { Total } \\
\text { (n) }\end{array}$} & \multirow[b]{2}{*}{ OR } & \multirow[b]{2}{*}{ CI $95 \%$} & \multirow[b]{2}{*}{ Nilai $p$} \\
\hline & $\begin{array}{c}\text { Risiko } \\
\text { CVD (n) }\end{array}$ & $\begin{array}{c}\text { Bukan } \\
\text { Risiko CVD } \\
(\mathrm{n})\end{array}$ & & & & \\
\hline \multicolumn{7}{|l|}{ Energi } \\
\hline Lebih & 36 & 15 & 51 & 0,30 & $0,08-1,15$ & $0,068^{*}$ \\
\hline Cukup & 19 & 5 & 24 & 0,48 & $0,10-2,24$ & $0,451 * *$ \\
\hline Kurang & 24 & 3 & 27 & Pembanding & & \\
\hline \multicolumn{7}{|l|}{ Protein } \\
\hline Lebih & 43 & 15 & 58 & 1,10 & $0,34-3,61$ & $1,000 * *$ \\
\hline Cukup & 23 & 3 & 26 & 2,94 & $0,61-14,38$ & $0,240 * *$ \\
\hline Kurang & 13 & 5 & 18 & Pembanding & & \\
\hline \multicolumn{7}{|l|}{ Lemak } \\
\hline Lebih & 27 & 14 & 41 & 0,39 & $0,13-1,15$ & $0,081 *$ \\
\hline Cukup & 22 & 3 & 25 & 1,47 & $0,33-6,52$ & $0,725 * *$ \\
\hline Kurang & 30 & 6 & 36 & Pembanding & & \\
\hline \multicolumn{7}{|l|}{ Karbohidrat } \\
\hline Lebih & 34 & 14 & 48 & 0,29 & $0,08-1,12$ & $0,088^{*}$ \\
\hline Cukup & 20 & 6 & 26 & 0,40 & $0,09-1,80$ & $0,286^{* *}$ \\
\hline Kurang & 25 & 3 & 28 & Pembanding & & \\
\hline $\begin{array}{c}\text { Aktivitas fis } \\
\text { Kurang } \\
\text { Cukup }\end{array}$ & $\begin{array}{l}25 \\
58\end{array}$ & $\begin{array}{c}1 \\
18\end{array}$ & $\begin{array}{l}26 \\
76\end{array}$ & 7,76 & $0,98-61,33$ & 0,038 \\
\hline
\end{tabular}

*Uji yang digunakan uji Chi-Square

**Uji yang digunakan uji Fisher

Berdasarkan tabel III, hasil penelitian ini menujukkan adanya hubungan yang tidak bermakna antara aktivitas fisik terhadap rasio kolesterol total/HDL ( $\mathrm{p}=0,038$; nilai CI 95\%: 0,98-61,33). Responden dengan aktivitas fisik yang kurang mempunyai kemungkinan 7,76 kali untuk mengalami risiko CVD dibandingkan dengan responden yang melakukan aktivitas fisik secara cukup. Hal ini sejalan dengan penelitian yang dilakukan oleh Lita (2016) bahwa aktivitas fisik mempunyai hubungan yang tidak bermakna terhadap faktor risiko CVD. Hasil yang didapatkan berbeda dengan penelitian yang dilakukan oleh Sumosardjuno (2007) bahwa orang yang banyak melakukan aktivitas fisik 
dalam kegiatan sehari-harinya memiliki risiko CVD lebih sedikit dibandingkan dengan orang yang kurang melakukan aktivitas fisik. Demikian pula dengan hasil penelitian Rahmawati (2009) aktivitas fisik dapat meningkatkan kadar HDL dalam darah sehingga faktor risiko CVD dapat dikurangi. Aktivitas fisik juga dapat menurunkan berat badan sehingga lemak yang berlebihan berkurang bersama-sama dengan menurunnya kadar LDL dalam darah (Delavar et al., 2011).

Keterbatasan penelitian ini yaitu SQFFQ bersifat retrospektif atau ketepatan informasi bergantung pada daya ingat responden dan membutuhkan motivasi dan kejujuran yang tinggi untuk memberitahu data asupan makanannya, kurang akurat untuk asupan gizi pada makanan dengan resep yang berbeda-beda, responden kesulitan untuk mengestimasi porsi makanan yang bervariasi (Thompson dan Subar, 2013).

\section{KESIMPULAN}

Hasil penelitian ini menunjukkan bahwa tidak ada hubungan yang bermakna antara aktivitas fisik dan angka kecukupan gizi makronutrien terhadap rasio kolesterol total/HDL pada orang dewasa di Desa Kepuharjo, Kecamatan Cangkringan, Sleman, Yogyakarta.

\section{DAFTAR PUSTAKA}

American Heart Assosiation, 2015. What is Cardiovascular Disease. AHA (Online), http://www.heart.org/HEARTORG/Caregiver/ Resources/ What is Cardio vascular Disease/ What-is-

Cardiovascular-

DiseaseUCM301852Article.jsp accessed 15 March 2016.

Anggraeni, F., 2008. Hubungan antara Gaya Hidup dengan Status Kesehatan Lansia Binaan Puskesmas Pekayon Jaya Kota Bekasi Tahun 2008, Skripsi, Universitas Indonesia, Jakarta, pp.57-60.

Arisman, 2011. Obesitas, Diabetes Melitus, dan Dislipidemia : Konsep, Teori, dan
Penanganan Aplikatif, EGC, Jakarta, hal. 122.

Baecke, J.A.H., Burema, J., Frijters, E.R., 1982. A Short Questionnaire for the Measurement of Habitual Physical Activity in Epidemiological Studies, Am J Clin Nutr., 36: 936-942.

Chen, Y., Copeland, W., Vedanthan, R., Grant, E., Lee, J., Gu, D., 2013. Association between Body Mass Index and Cadriovascular Disease Mortality in East Asians and South Asians: Pooled analysis of Prospective Data from the Asia Cohort Consoetium, BMJ., 347:f5446.

Coates, J., Colaiezzi, B., Fiedler, J., Wirth, J., Lividini., et al., 2012. Applying Dietary Assessment Methods for Food Fortification and Other Nutrition Programs, Geneva., p. 30.

Dahlan, M.S., 2014. Statistik untuk Kedokteran dan Kesehatan, Edisi 6, Salemba, Jakarta.

Delavar, M. et al., 2011. Physical activity, nutrition, and dyslipidemia in middleaged women. Iranian journal of public health, (Online), http://www.pubmedcentral.nih.gov/articl erender.fcgi? artid $=3481733 \&$ tool $=$ pmce ntrez\&rendertype $=$ abstract accessed 15 March 2016.

Dinas Kesehatan Daerah Istimewa Yogyakarta., 2013. Profil Kesehatan Daerah Istimewa Yogyakarta Tahun 2013, Depkes., (Online), http://www.depkes.go.id/resources/down load/profil/PROFIL_KES_PROVINSI_2 012/14_Profil_Kes.Prov.DIYogyakarta 2012.pdf diakses tanggal 13 Maret 2016. Dipiro, J.T., Wells, B.G., Schwinghammer, T.L., $\quad$ Dipiro, $\quad$ C.V., 2008. Pharmacotherapy A Pathophysiologic Approach, $7^{\text {Th }}$ edition, McGraw-Hill Companies, United States, pp. 429-450.

Ekasari, D.O., 2013. Perbedaan Intake Karbohidrat, Protein, Lemak, dan Kolesterol antara Penderita Penyakit Jantung Koroner dan Penyakit Jantung non-Koroner Pasien Rawat Jalan di 
RSUD Dr. Moewardi, Skripsi, Universitas Muhamadiyah Surakarta.

Elizabeth, J. B, Lutsey, P.L., Windham, B.G., Folsom, A.R., 2012. Physical Activity and Cardiovascular Disease in African Americans in ARIC, Univeristy of Minnesota, American College of Sports Medicine., (Online), https://www.ncbi.nlm.nih.gov/pmc/articl es/PMC3622814/pdf/nihms-428377.pdf, accessed 27 March 2017.

Fridawanti, A. P., 2015. Hubungan Antara Asupan Energi, Karbohidrat, Protein, dan Lemak terhadap Obesitas Sentral pada Orang Dewasa di Desa Kepuharjo, Kecamatan Cangkringan, Yogyakarta, Skripsi, Universitas Sanata Dharma.

Ghanbari, B., Khaleghparast, S., Ghadrdoost, B., Bakhshandeh, H., 2014. Nutritional Status and Coronary Artery Disease: A Cross Sectional Study, Iran Red Crescent Medicial Journal., 16(3):e13841

Gupta K., Mathur K., Sankhla M., 2015. Influence of Menstrual Cycle Phases On Serum Level of Lipids and Lipoprotein Ratios in Eumenorrheic Women., Sch. J. App. Med., Sci; 3 (4c), 1769-72.

Hearth UK, 2015. Risk Factor for Cardiovascular Disease (CVD), The Cholesterol Charity, (Online), https://heartuk.org.uk/files/uploads/docu ments/huk_fs_mfsI_riskfactorsforchd_v 2.pdf, accessed 26 March 2017.

Huang, J., Huang, S., Li, R., Wang, L., Chen, Y., Tang, F., 2014. Effects of Nutrition and Exercise Health Behaviors on Predicted Risk of Cardiovascular Disease among Wqorkers with Different Body Mass Index Levels, International Joural Research Public Health., 11, 4664-4675.

Ignarro, L., Balestrieri, L., \& Napoli, C., 2007. Nutrition, Physical Activity, and Cardiovascular Disease: An Update, Elsevier, 73 (10), pp.326-340.

Lita, M.M., 2016. Hubungan Aktivitas Fisik Terhadap Obesitas Sentral pada Orang Dewasa di Desa Kepuharjo Cangkringan Sleman Yogyakarta, Skripsi, Universitas
Sanata Dharma.

Loong, S., Mayulu, N., Kawengian S., 2013. Hubungan antara Asupan Zat Gizi Makro dengan Obesitas pada Wanita Usia Subur Peserta Jamkesmas di Puskesmas Wawonasa Kecamatan Sengkil Manado, Journal e-Biomedic, Volume 1, No. 1, 607-613.

McPhee, J.S., dan Ganong, W.F., 2011. Patofisiologi Penyakit : Pengantar Menuju Kedokteran Klinis, 5th edition, Prentice-hall International Inc., New Jersey, pp.334-335.

Menteri Kesehatan Republik Indonesia., 2013. Angka Kecukupan Gizi yang Dianjurkan Bagi Bangsa Indonesia, (Online),

http://himagizi.lk.ipb.ac.id/files/.../akg20 13-Hardin-Final-Edit bersama.pdf, diakses tanggal 24 Maret 2016.

Milan, J., Pinto, X., Munoz, A., Zuniga, M., Rubies-Prat, J., Pallardo, L, P., 2009. Lipopretein ratio: Physiological Significance and Clinical Usefulness in Cardiovascular Prevention, Vascular Health and Risk Management., 5 757765.

Miles, L., 2007. Physical Activity and Health, British Nutrition Foundation., 32(4) pp. 314-363.

Mohammadifard, N., Nazeni, M., Sarrrafzadegan, N., Nouri, F., Sajjadi, F., et al., 2013. Body Mass Index, Waist-circumference and Cardiovascular Disease Risk Factors in Iranian Adults: Isfahan Healthy Heart Program, Journal Health Popular Nutrition, (3);388-397.

National Health and Nutrition Examination Survey (NHANES), 2007. Anthropometry Procedures Manual, $C D C$, UK, pp. 19,16.

National Institute of Health, 2012. Measuring Cholesterol Levels, NIH., (Online), https://www.nlm.nih.gov/medlineplus/m agazine/issues/summer12/articles/summ er1pg6-7.html, accessed 26 May 2016.

Pereira, T., 2012. Dyslipidemia and Cardiovascular Risk: Lipis Ratios as Risk Factors for Cardiovascular Disease, Endocrinology and Metabolism, Intech. 
Rahmawati, A. C., 2009. Hubungan Asupan Lemak dan Aktivitas Fisik dengan Rasio Antara Total Kolesterol dan High Density Lipoprotein (HDL) pada Penderita Penyakit Jantung Koroner di Poliklinik Jantung RSUD Dr. Moewardi Surakarta, Skripsi, Universitas Muhamadiyah Surakarta.

Saevageot, N., Alkerwi, A., Albert, A., Guilaume, M., 2013. Use of Food Frequency Questionnarire to Assess Relationship between Dietary Habits and Cardiovascular Risk Factor in NESCAV Study: Validation With Biomarkers, Nutritionj, 12(143), 2.

Shay, C. M., Stamler, J., Dyer, A. R., Brown, I. J., Chan, Q., et al., 2012. Nutrient and Food Intakes of Middle-aged Adults at Low Risk of Cardiovascular Disease: The International Study of Macro/micronutrient and Blood Pressure (INTERMAP), Europan Journal Nutrition, 51:917-926.

Sudikno., Herdayati, M., dan Besral., 2010. Hubungan Aktivitas Fisik dengan Obesitas pada Orang Dewasa di Indonesia, Gizi Indon., 33(1):37-49.

Sumosardjuno, S., 2007. Aktivitas Bergerak Kurangi Risiko PJK, (Online), http://www.idi.or.id diakses tanggal 1 Oktober 2016.

Thompson, F.E., Subar, A.F., 2013. Chapter 1. Dietary assessment methodology, Nutrition in the Prevention and Treatment of Disease, Academic Press, San Diego, p. 11.

Valentino, G., Bustamante, M.J., Orellana, L., Krämer, V., Durãn, S., et al, 2015. Body fat and its relationship with clustering of cardiovascular risk factors, Nutricion Hospitalaria., 31 (5), 22532260.

Widiantini, W., Tafal, 2014. Aktivitas Fisik, Stres, dan Obesitas pada Pegawai Negeri Sipil, Jurnal Kesehatan Masyarakat Nasional., 8 (7), 330-336.
World Health Organization, 2008a. Obesity, WHO, (Online), http://www.who.int/gho/ncd/riskfators/o besity text/en/ accessed 3 June 2016.

World Health Organization, 2008b. WHO Country Cooperation Strategy 20072011, WHO,(Online) http://www.who.int/countryfocus/cooper ationstrategy/ccsidnen.pdf accessed 15 March 2016.

World Health Organization, 2015a. Cardiovascular Disease, WHO, (Online), http://www.who.int/cardiovasculardiseas es/en/ accessed 14 March 2016.

World Health Organization, 2015b. Obesity, WHO, (Online), http://www.who.int/topics/obesity/en/ , accessed 17 March 2016.

World Health Organization, 2015c. Physical Activity, $\quad W H O, \quad$ (Online), http://www.who.int/topics/physicalactivi ty/en/ accessed 16 March 2016.

World Health Organization, 2015d. Physical Activiy and Adults, WHO, (Online), http://www.who.int/dietphysicalactivity/ factsheetadults/en/ accessed 16 March 2016.

World Health Organization., 2016a. Cardiovascular Disease, WHO, (Online), http://www.who.int/mediacentre/factshe ets/fs317/en/, accessed 8 March 2016.

World Health Organization., 2016b. Dietary Recommendation Nutritional Requirements, WHO, (Online), http://www.who.int/nutrition/topics/nutr ecomm/en/, accessed 14 March 2016.

World Heart Federation., 2016c. Cardiovascular Disease Risk Factors, WHO, (Online), http://www.world-heartfederation.org/cardiovascularhealth/cardiovascular-disease-riskfactors/, accessed 28 March 2016.

Yuliantini, E., Sari, A., Nur, E., 2015. Hubungan Asupan Energi, Lemak dan Serat dengan Rasio kadar kolesterol Total/HDL, Penelitian Gizi dan Makanan, Vol.38(2):139-147. 